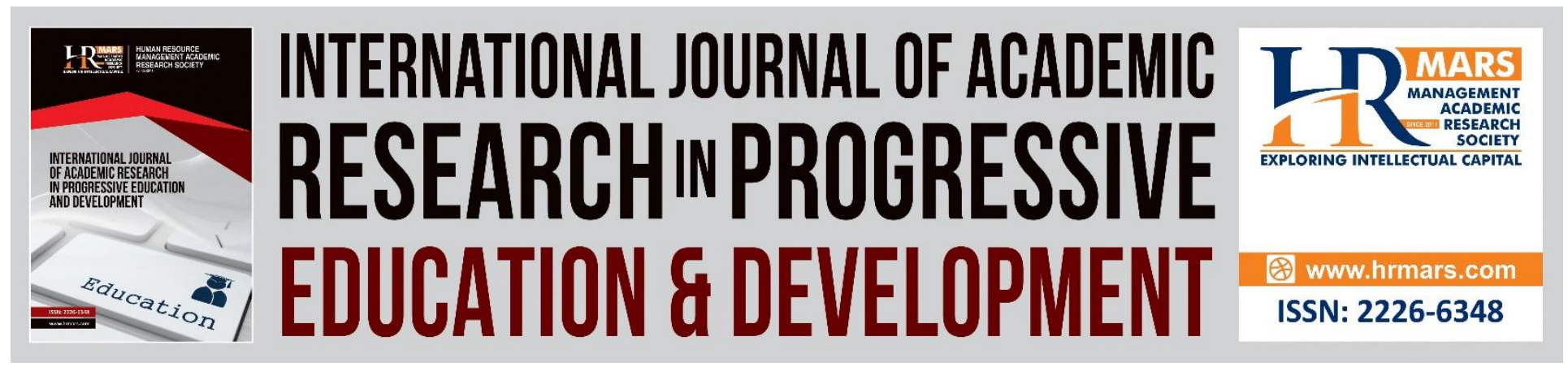

\title{
Issues and Challenges of Subject Leadership Competency for Malaysian Head of Science Panels (HoSP)
}

Adawati Suhaili, Kamisah Osman, Mohd Effendi @ Ewan Mohd Matore

To Link this Article: http://dx.doi.org/10.6007/IJARPED/v9-i2/7296

DOI:10.6007/IJARPED/v9-i2/7296

Received: 20 March 2020, Revised: 25 April 2020, Accepted: 17 May 2020

Published Online: 18 June 2020

In-Text Citation: (Suhaili et al., 2020)

To Cite this Article: Suhaili, A., Osman, K., \& Matore, M. E. @ E. M. (2020). Issues and Challenges of Subject Leadership Competency for Malaysian Head of Science Panels (HoSP). International Journal of Academic Research in Progressive Education and Development, 9(2), 229-241.

Copyright: (C) 2020 The Author(s)

Published by Human Resource Management Academic Research Society (www.hrmars.com)

This article is published under the Creative Commons Attribution (CC BY 4.0) license. Anyone may reproduce, distribute, translate and create derivative works of this article (for both commercial and non-commercial purposes), subject to full attribution to the original publication and authors. The full terms of this license may be seen at: http://creativecommons.org/licences/by/4.0/legalcode

Vol. 9(2) 2020, Pg. 229 - 241

http://hrmars.com/index.php/pages/detail/IJARPED

JOURNAL HOMEPAGE

Full Terms \& Conditions of access and use can be found at http://hrmars.com/index.php/pages/detail/publication-ethics 


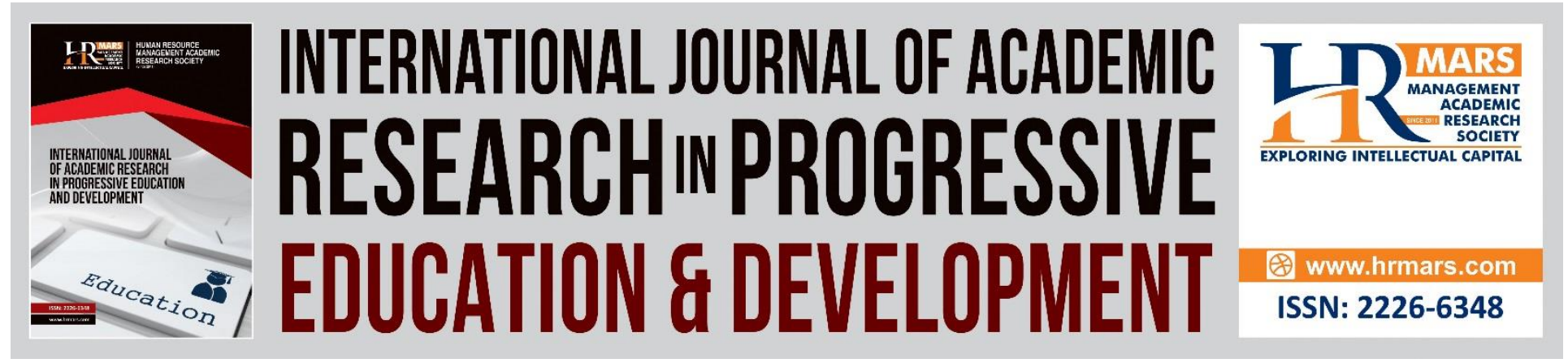

\title{
Issues and Challenges of Subject Leadership Competency for Malaysian Head of Science Panels (HoSP)
}

\section{Adawati Suhaili, Kamisah Osman, Mohd Effendi @ Ewan Mohd Matore}

Faculty of Education, National University of Malaysia, Selangor, Malaysia

\begin{abstract}
The rapid development of Science and Technology has driven Malaysia to reform education to stay relevant. The low achievement of student scientific literacy in the Trends in International Mathematics and Science Study (TIMSS) and the Program for International Student Assessment (PISA) has raised concerns with the Ministry of Education, Malaysia (MoE) where the role of Head of Science Panel (HoSP) is seen as a change agent in facilitating student achievement. Highlights of previous studies have shown that subject leadership can improve the quality of teaching and learning. To guide teachers more effectively, subject leader such as HoSP must be competent in their leadership. However, weaknesses in the aspect of HoSP leadership in Malaysia have caused them to be less competent and less confident in leading Science teachers. The main objective of this paper is to provide an overview of the issues and challenges faced by HoSP in their leadership role. Subsequently, several proposed solutions are also discussed. The administrative and management duties of the committee and the responsibility of teaching at one time have been burdensome and can lose focus on their role as subject leader. This emphasis is significant to the MoE in strengthening HoSP leadership competency to focus on enhancing students scientific literacy achievement in Malaysia.
\end{abstract}

Keywords: Subject leadership, Competency, Issues, Challenges, Head of Science Panel, Malaysia.

\section{Introduction}

Educational reforms or changes have made a massive impact on the educational system and climate globally (Barber \& Mourshed, 2007; Cheng \& Walker, 2008; Klentschy, 2008). Previous researchers have also argued that education reform is essential to be implemented as education is vital in developing civilised societies and developed countries (Hallinger \& Bryant, 2013; MoE, 2013; Li \& Du, 2016). Most countries have taken steps towards improving the education system so that they can compete in a knowledge-based world economy (Bush et al., 2019). Bush et al. 
(2019) also stated that Malaysia is following the same path as Malaysia emulates the success of other countries through the concept of lending policy by establishing the Malaysian Education Blueprint (MEB) 2013-2025.

Among the key objectives of the MEB 2013-2025 are the top one-thirds in international assessments, the Trends in International Mathematics and Science Study (TIMSS) and the Program for International Student Assessment (PISA) by 2025 (MoE, 2013). Although various efforts have been made to improve achievement, however, the scientific literacy results in PISA, 2015 showed that achievement occurs at a moderate level (Moe, 2016). The achievement in scientific literacy still far from the target by MOE and below the minimum level determined by the OECD (OECD, 2019b). Meanwhile, a report on scientific literacy competencies for cohorts of form two and form three in 2017 conducted by the Ministry of Education Malaysia (MOE) found that most students attained low achievement levels of $54.7 \%$ for the first screening and $54.7 \%$ for the second screening (MoE, 2018). This situation has been a major concern for the MoE as various teaching and learning improvement programmes have been disclosed to Science subject teachers but students' achievement is still at an alarming rate. The situation continues until today, and according to the PISA 2018 results announced by the OECD, Malaysia's position is still below the minimum level set by the OECD (OECD, 2019b).

The quality of teaching and learning of teachers is influenced by the leadership of his or her head of department with a mission and vision that emphasised student achievement (CSTP, 2009; Hammond, 1999; Hanuscin, Rebello \& Sinha, 2012; Leithwood et al., 2004; Turner, 2005; Wenner \& Campbell, 2016). Considerable research attention needs to devote to the role of HoSP as the leader of the teachers in his department, also as a significant mean in improving the quality of teaching that leads to maximizing student achievement. A number of recent studies have reported that leaders have the ability to lead schools through improving teacher collaboration, disseminating best practices, encouraging teacher professional learning and providing assistance to various issues concerning the subject matter (Curtis, 2013; Muijs \& Harris, 2003; 2006).

This is further reinforced by the implementation of the MEB 2013-2025 policy in the fifth shift which aims to ensure that every school in Malaysia will have high-quality leaders (MoE, 2013). The ministry will ensure that a high performing principal and headmaster will be stationed at each school and will be assisted by a team of middle leaders, including a competent head department and head panel (Moe, 2013). It aims to create an effective school instructional leadership team that is capable of driving school performance to excellence (MoE, 2013). Male (2006) also suggested that leaders needed to possess high-quality skills and personalities as well as knowledge in their field to perform their tasks effectively. Only competent leaders can achieve satisfactory results through their leadership (Eddy, 2013). Therefore, in order to produce a competent and quality Science subject leader, the issues and challenges should be identified and the propose solutions are respectively discussed. Thompson reported that 'leadership development should not be left to change, however, should be a part of a planned effort at all levels' (Thompson, 2010). This provides an emerging research area for the current author's study of leadership preparation for HoSP. In Malaysia, the subject leadership of secondary and primary schools are called the head of department and head panel respectively. For this study, the title head panel is used to refer to both categories. 
Vol. 9, No. 2, 2020, E-ISSN: 2226-6348 @ 2020 HRMARS

\section{Issues of Subject Leadership Competency}

The issue of HoSP inability to lead the Science Committee in Malaysia has been raised since the 20th century. There are some research evidences in Malaysia have found that the issue of HoSP leadership's inability is due to several factors. A study conducted by Ngui (2000) revealed that the level of competency for HoSP at Primary School in Kuching Divison, Sarawak is low mainly the elements of supervision, orientation and use of committee members, curriculum development and committee management. Ngui claimed that this phenomenon occurs because HoSP is unclear about his role and role as department leader and this finding has also been stated by (Peacock, 2014). Ngui (2000) has also suggested that HoSP should be equipped with appropriate work competencies to enable them to support the professional development of other Science teachers and to be effective change agents in implementing curriculum reforms (Larkin, Seyforth \& Lasky 2009).

Meanwhile, Shafila (2008) argued that the level of curriculum and instructional leadership of HoSP in a Pontian District, in Johor was overall at a high level. However, there are HoSP who still with low management skills. The management skills are seen in assessing the effectiveness of programmes held during the year with the lowest mean value of 3.65. They concluded that it may be due to lack of exposure to conduct post-mortem programme and lack of emphasis by the administrator on the programme evaluation process. A study of middle-level leadership training conducted among head panels that also involved HoSP in primary school at Muar District by Hafiz (2014) found that there were aspects of hiring skills that the head panels group had not mastered. $\mathrm{He}$ also noted that there were still issues regarding the implementation of lamination among head panels in his study. A number of teachers have claimed that they expected the head panels to provide feedbacks after the teaching and learning supervision. Such evidence revealed that more effort is needed in improving the head panels leadership competency as a reformation agent in the school. However, the review of literature studied by Fatin et al. (2014) from 2001 to 2010 found that there were only two relevant studies; Ahmad (2002) and Mazlan (2005). Their findings indicated that monitoring of teaching and learning sessions by HoSP has not reached a satisfactory level.

A study by Javadi, Bush and Ng (2017) revealed the middle leadership in international schools conducted at four International Schools in Malaysia, and found that limited barriers and concepts for head panels including HoSP and teachers to practice leadership. Leadership is intended as a mean to promote teacher's leadership among themselves. It suggests that the involvement of the head panel's leadership as a middle-class leader in Malaysia is still limited to traditional classes and informal discussions boundaries (Wan, 2017). The role of the head panels and the head of department for a particular subject has been identified as an important component that contributes significantly to managing change at the department and school level (Busher, 2005; Busher \& Harris, 1999; Harris, Jamieson \& Russ, 1997; Spillane, 2013; Turner, 2005). Thus, in western countries' research related to subject leadership continues to evolve in line with the changes in international curriculum standards. It has been proven that competent Science subject leaders have been recognised as an agent of change that is a catalyst for effective implementation of changes in the Science curriculum (Hammond, 1999; Hanuscin, Rebello \& Sinha, 2012; Klentschy, 2008; Larkin, Seyforth \& Lasky, 2009; Peacock, 2014; Sinha \& Hanuscin, 
Vol. 9, No. 2, 2020, E-ISSN: $2226-6348$ @ 2020 HRMARS

2017). Therefore, the challenges faced by the HoSP in Malaysia are discussed and to identify the opportunities and scopes to improve the issues addressed in this study.

\section{Challenges of Subject Leadership}

The challenges for the school leaders nowadays are to constantly improve their leadership roles specifically in managing the curriculum reforms and issues that take place in the education globally. According to Harris and Jones (2017) the idea of middle-level leadership has emerged as a reform strategy in the leadership system where the role of middle-level leaders is acknowledged as crucial. Fullan (2015) also noticed that the middle leaders show their capabilities and effective internal relationships between a high ranking leader to the lower level of school and community followers to pursue higher performance. Recognising the importance of developing middle leadership as a key agent in curriculum reform in schools, MoE has given the responsibility to the National Institute of Educational Management and Leadership or Institute Aminuddin Baki (IAB) to organize the leadership training programme. IAB, which is the country's main leadership training and development centre has been tasked with providing leadership training to middle leaders starting the year 2017 (IAB, 2016).

The fourteen competencies required by the middle leaders as outlined by the IAB are proactive, communication, achievement orientation, teamwork, creativity and innovation, curriculum focus, capacity building, knowledge sharing, problem-solving, change management, supervision, instructional development, decision making and social management (IAB, 2016). IAB (2016) stated, all elements of competencies that have been listed should be learned and built by the middle leaders in the Leadership Course for Middle Leader (LCML) in order to improve the head of departments and the head panel leadership competencies. The LCML program is implemented in parallel with the intention of PPPM 2013-2025 in its fifth shift to improve the quality of educational leadership (MOE, 2013). Unfortunately, efforts to improve the quality of middle leadership in the second wave do not apply to all the head panels because LCML courses are offered only to head panels for primary school covering a wide range of subjects (IAB, 2016). The course is unable to accommodate a large number of the head panels for all subjects in schools in Malaysia with a limited number of courses and long waiting to be selected as a course participant. In a study by Islam, Karmaker and Paul (2019) on the challenges faced by the Head of Department (HoD) at Tertiary College in Bangladesh were due to the lack of training and leadership courses provided.

Meanwhile, some researchers have found that the issues related to HoSP leadership in Malaysia are due to the lack of relevant research conducted (Fatin et al., 2014; Javadi, Bush \& $\mathrm{Ng}$, 2017). The findings of a study conducted by Javadi, Bush and Ng (2017) found that their study was the first in the context of international leadership in international schools conducted in Malaysia. They found that there were also limited studies in public schools related to middle leadership. The phenomenon becomes a new research area mainly in Science education in Malaysia where more attention is given to study the HoSP leadership competency development as an effective change agent in Science curriculum reform (Hammond, 1999; Hanuscin, Rebello \& Sinha, 2012; Sinha \& Hanuscin, 2017; Turner, 2005; 2012).

The problem is not only occurring in Malaysia but internationally. As mentioned by Wenner and Campbell (2017) in their study, they found that there were only three studies related 
to teacher leadership for Science subjects between 2008-2012. Among them are Hofstein, Carmeli and Shore (2004), Singh et al. (2012) and Hanuscin, Rebello and Sinha (2012). This means that inadequate of researches in the relevant field will limit the availability of information about the dissemination of policy (Ball et al., 2008). Therefore, Malaysia should take appropriate initiatives and actions to create a new area of research related to HoSP leadership to achieve its goals, reaching the top one-third in TIMMS and PISA assessments by 2025.

The role HoSP leadership in supporting change in Science education has been proven to be relevant as mentioned in various researchers (Hanuscin, Rebello \& Sinha, 2012; Klentschy, 2008; Peacock, 2014; Sinha \& Hanuscin, 2017). The practice of continuing professionalism practised by school leaders, especially teachers of advanced and developing countries has brought them to the top of the PISA (OECD, 2019a) assessment. Based on this key point, it is anticipated that there will still be issues in HoSP leadership competencies, as Malaysian students achievement in scientific literacy for TIMSS 2015 and PISA 2018 are still lagging behind in comparison with other developed countries (MoE, 2016; OECD, 2019b). The PISA 2018 report (OECD, 2019b) also indicated that Malaysia position in scientific literacy is below the minimum set by the Organization for Economic Co-operation and Development (OECD). To cope with PISA 2021 and bridging the gaps in its goals, a continuous professional development training is essential to be given to the HoSP in helping them to accelerate the student achievement in science literacy by 2025.

Effective, continuous professional development among the head panels gives a significant impact to improve the teacher quality and ensuring the improvement of student achievement (Berry, Daughtrey \& Wieder, 2010; Fleming, 2014; Foster, 2005; Hammond, 1999; Hanuscin, Rebello \& Sinha, 2012; Harris, Jamieson \& Russ, 1997; Harris \& Jones, 2010; Katzenmeyer \& Moller, 2009; Leask \& Terrell, 2014). However, to develop HoSP leadership competencies requires specialised models that can enhance their competencies in the context of tasks in a specific organisational environment (Boyatzis, 1982; 2008; 2011; Lucia \& Lepsinger, 1999; Megahed, 2018; Spencer \& Spencer, 1993; TTA, 1998; Turner, 2005; 2012). Therefore, based on these models, programme coordinators will be able to provide the right programme modules to ensure that the programme's impact can fully develop the performance and competencies required by the HoSP (Hanuscin, Rebello \& Sinha, 2012; Klentschy, 2008; Lucia \& Lepsinger, 1999; Peacock, 2014; Sinha \& Hanuscin, 2017). However, there is no specific model of leadership competency for the purpose of developing HoSP professionalism in Malaysia.

As such, in addition to providing a focused teaching and learning improvement program, the more also needs to focus and support the HoSP leadership competency enhancement programme. A number of scholars in the previous studies suggested that continuous professional training is crucial, especially in teacher leadership to enhance the educational attainment of developed countries in PISA (Crow, Lumby \& Pashiardis, 2008; Hairon \& Tan, 2015; OECD, 1998; 2019a). Figure 1 shows the overall summary of the issues and challenges faced by the HoSP in Malaysia in its role as subject leadership.

\section{Conclusion}

This paper provides an overview of issues and challenges related to subject leadership, especially the Head of Science Subject Panels (HoSPs) in Malaysia. The data on HoSPs leadership in Malaysia 
addresses major issues on the unsatisfactory level of leadership competencies which include the elements of supervision skill, leading and managing of Science committee members, managing teaching and learning in Science curriculum, effective deployment of Science committee members, evaluation skill especially for evaluating programme's effectiveness, mentoring skill and reflection skill. The reflection skill refers to skills in providing feedback after the monitoring and observing of classroom teaching and learning session that carried out by the Science teachers. Nevertheless, the review of existing literature on HoSPs leadership competencies revealed that the reflection skill after the teaching and learning monitoring sessions has not reached to a satisfactory level. The current study investigates that limitation for the HoSPs to practice leadership in the Science committee. Review of past literatures show that there is inadequate research have been done concerning the Science subject leadership. It causes the limitation of relevant information in enhancing the existing policies towards the continuous development of HoSPs professionalism. In addition, the limitation in attending leadership courses and training opportunity organized by the MoE is among the major challenges to improve the HoSPs leadership competency in Malaysia. This means that a majority of the HoSPs are assigned the post with no management training, sufficients skills and knowledge. Moreover, the practice of subject leadership effectiveness is hindered by the lack of opportunities and support to practise leadership by a school leader. Therefore, as an effort to elevate HoSPs as an effective change agent in Science curriculum reform in Malaysia and bridging the gaps in its goals, requires specialised models to enhance their competencies in specified tasks. Based on these models, program coordinators will be able to provide the right programme modules that give high impact in developing the performance and competencies of HoSPs professionalism in Malaysia. 


\section{Figure}

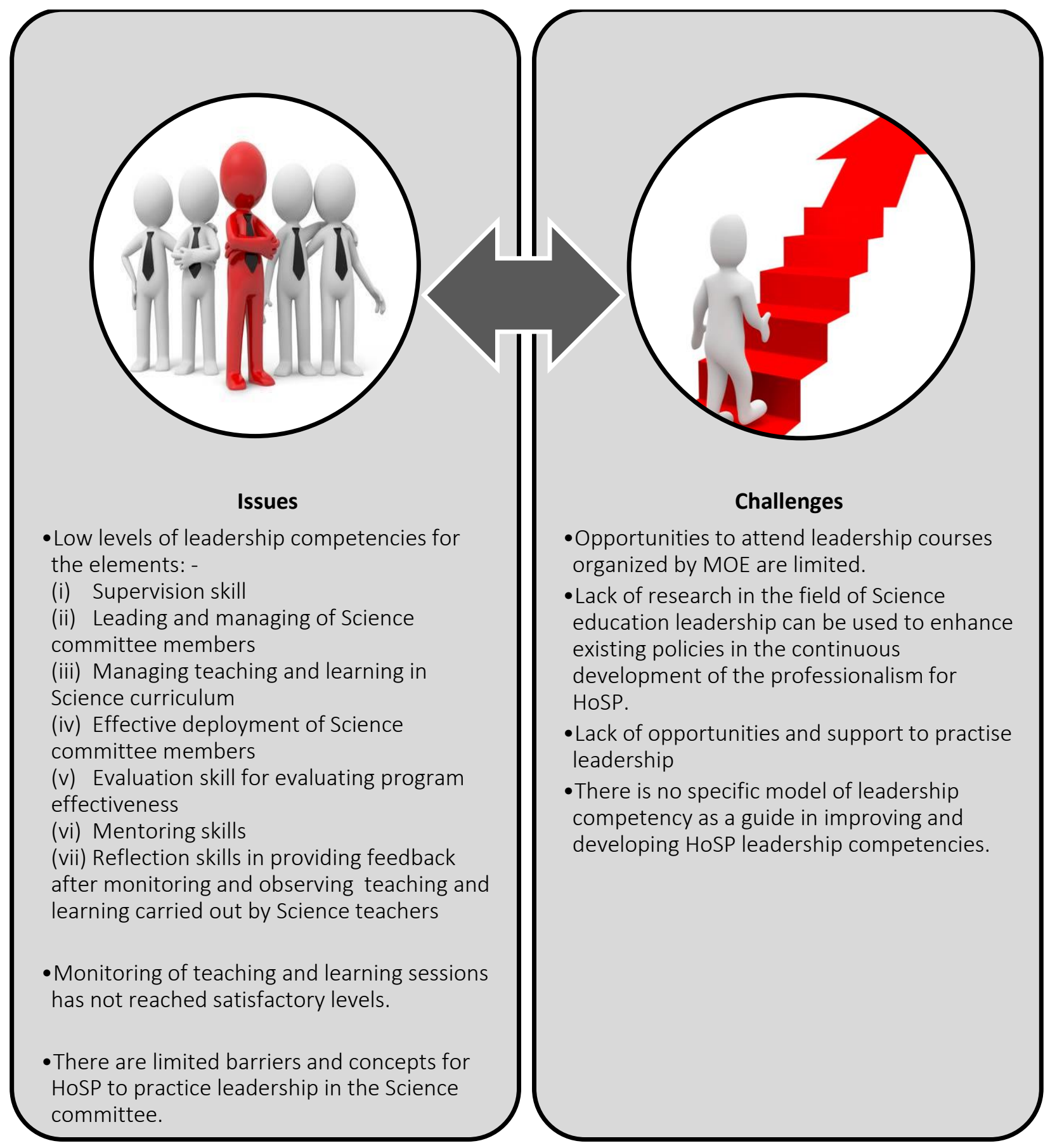

Figure 1. Summary of issue and challenges on subject leadership competency for Malaysian Head of Science Panel (HoSP) 
INTERNATIONAL JOURNAL OF ACADEMIC RESEARCH IN PROGRESSIVE EDUCATION AND

DEVELOPMENT

Vol. 9, No. 2, 2020, E-ISSN: 2226-6348 @ 2020 HRMARS

\section{Corresponding Author}

Adawati Suhaili, Malaysia, p92631@siswa.ukm.edu.my, Faculty of Education, National University of Malaysia, 43600 UKM, Bangi Selangor.

\section{Acknowledgement}

The authors would like to thank the following people for their contribution to the work reported in this paper: Nurul Fadly Habidin lecturer for Sultan Idris Education University (UPSI), Tanjung Malim, Malaysia, Saifulbahri Abdul Rahman, School Teacher, Semenggok Primary School, Sarawak, Malaysia and Johan Severinus Tati, MARA Technology University (UiTM), Shah Alam, Malaysia.

\section{References}

Ahmad, S. M. Y. (2002). Implementation of Teacher Thinking Skills in Primary School Science Subject: A Case Study. Unpublished Master Theses, National University of Malaysia.

Aminuddin Baki Institute. (2016). Guideline e-LCML: Guide book for LCML. Retrieved from http://lcml.iab.edu.my/pluginfile.php/2249/block_html/content/BUKU\%20KECIL\%20LCM L.pdf

Ball, D. L., Thames, M. H., \& Phelps, G. (2008). Content knowledge for teaching: What make it special? Journal of Teacher Education, 59(5), 389-407.

Barber, M., \& Mourshed, M. (2007). How the world's best-performing school systems come out on top. McKinsey \& Company, Inc. (2008, February 29). McKinsey Education Report. Retrieved from www.nctq.org/p/publications/docs/mckinsey_education_report.pdf

Berry, B., Daughtrey, A., \& Wieder, A. (2010). Teacher leadership: Leading the way to effective teaching and learning. New York: NY: Center for Teaching Quality.

Boyatzis, R. E. (1982). The competent manager:a model for effective performance. New York: Wiley.

Boyatzis, R. E. (2008). Competencies in the 21st century. Journal of Management Development, 27(1), 5-12.

Boyatzis, R. E. (2011). Managerial and Leadership Competencies: A Behavioral Approach to Emotional, Social and Cognitive Intelligence. Journal of Business Perspective, 15(2), 91-100.

Bush, T., Ng, A. Y. M., Wei, K. T., Chay, J., Glover, D., \& Lei, M. T. (2019). Education Policy in Malaysia: Implementation Challenges and Policy Proposals. The Policy Brief No. 7 Conference of Educational Leadership. Held by School of Education, University of Nottingham Malaysia, (2019, January), pg. 1-13. Retrieved from http://www.nottingham.edu.my/Education/documents/education-leadershipconference/The-HEAD-Foundation-Policy-Brief-No.-7-Educational-Policy-in-MalaysiaImplementation-Challenges-and-Policy-Proposals-Feb.pdf

Busher, H. (2005). Being a Middle Leader: Exploring Professional Identities. School Leadership \& Management, 25(2), 137-153.

Busher, H., \& Harris, A. (1999). Leadership of school subject areas: tensions and dimensions of managing in the middle. School Leadership and Management, 19(3), 305-317. 
INTERNATIONAL JOURNAL OF ACADEMIC RESEARCH IN PROGRESSIVE EDUCATION AND

DEVELOPMENT

Vol. 9, No. 2, 2020, E-ISSN: 2226-6348 @ 2020 HRMARS

Center for Strengthening the Teaching Profession (CSTP). (2009). Teacher Leadership Skills Framework. CSTP. Retrieved from http://cstp-wa.org/cstp2013/wpcontent/uploads/2014/06/Teacher-Leadership-Framework.pdf

Cheng, Y. C., \& Walker, A. (2008). When reform hits reality: The bottleneck effect in Hong Kong primary schools. School Leadership and Management, 28(5), 505-521.

Crow, G., Lumby, J., \& Pashiardis, P. (2008). Introduction: why a handbook on the preparation and development of school leaders? In Lumby, J., Crow, G., \& Pashiardis, P. (eds). International Handbook on the Preparation and Development of School Leaders. New York: Taylor and Francis.

Curtis, R. (2013). Findings a new way: Leveraging teacher leadership to meet unprecedented demands. Washington, DC: Aspen Institute.

Eddy, P. L. (2013). Developing leaders: The role of competencies in rural community colleges. Community College Review, 41(1), 20-43.

Fatin, A. P., Mohd, S. A., Mohammad, B. A., \& Salmiza, S. (2014). Factors led to decreasing participation of students in science stream: A meta-analysis study on theses highlight. Sains Humanika, 2(4), 63-71.

Fleming, P. (2014). Successful Middle Leadership in Secondary Schools. London: Routledge.

Foster, R. (2005). Leadership and secondary school improvement: Case studies of tensions and possibilities. International Journal of Leadership in Education, 8(1), 35-52.

Fullan, M. (2015). Leadership from the Middle: A System Strategy. Education Canada, 55(4), 2226.

Hafiz, R. (2014). Middle Leaders Mentoring Skills Practiced by the National School at Muar Division. Master Theses, University of Technology, Malaysia. Retrieved from http://eprints.utm.my/id/eprint/48506/1/HafizBinRamliMFP2014.pdf

Hairon, S., \& Tan, C. (2015). Developing Teachers Through Professional Learning Communities in Singapore and Shanghai. In Khine, M. S. (eds). Science Education in East Asia: Pedagogical Innovations and Research-informed Practices, pp. 407-424. Switzerland: Springer International Publishing.

Hallinger, P., \& Bryant, D. A. (2013). Synthesis of finding from 15 years of educational reform in Thailand: Lesson on leading educational change in East Asia. International Journal of Leadership in Education: Theory and Practice, 16(4), 399-418.

Hammond, P. (1999). How can a head of department affect the quality of teaching and learning? TTA Teacher - Researcher Grant Project 1997/98. Report in Tring School. Retrieved from http://www.leeds.ac.uk/educol/documents/000000933.htm

Hanuscin, D., Rebello, C., \& Sinha, S. (2012). Supporting the development of science teacher leaders-Where do we begin? Science Educator, 21(1), 12-18.

Harris, A., \& Jones, M. (2017). Leading Educational Change and Improvement at Scale: Some Inconvenient Truths About Educational Reform. International Journal of Leadership in Education, 20(5), 1-10.

Harris, A., \& Jones, M. (2010). Professional Learning Communities in Action. London: Leannta Press. 
Harris, A., Jamieson, I. M., \& Russ, J. (1997). Effective department in secondary school. In Harris, A., Bennett, N., \& Preedy, M. (eds). Organisational Effectiveness and Improvement. Milton Keynes: Open University Press.

Hofstein, A., Carmeli, M., \& Shore, R. (2004). The professional development of high school chemistry coordinators. Journal of Science Teacher Education, 15, 3-24.

Islam, M. R., Karmaker, P. R., \& Paul, A. S. (2019). Instructional Leadership as Head of the Department at Tertiary College in Bangladesh: Challenges and Solutions. IOSR Journal of Humanities and Social Science, 24(2), 1-8.

Javadi, V., Bush, T., \& Ng, A. M. Y. (2017). Middle leadership in international schools: evidence from Malaysia. School Leadership and Management, 37(5): 476-499.

Katzenmeyer, M., \& Moller, G. (2009). Awakening The Sleeping Giant: Helping Teacher Develop as Leaders. Third Edition. Thousand Oaks, CA: Corwin Press, Inc.

Klentschy, M. (2008). Developing Teacher Leaders in Science: Attaining and Sustaining Science Reform. Science Educator, 17(2), 57-64.

Larkin, D., Seyforth, S. C., \& Lasky, H. J. (2009). Implementing and sustaining science curriculum reform: A study of leadership practices among teachers within a high school science department. Journal of Research in Science Teaching, 46(7), 813-835.

Leask, M., \& Terrell, I. (2014). Development Planning and School Improvement for Middle Manager. London: Routledge.

Leithwood, K., Louis, K. S., Anderson, S., \& Wahlsttom, K. (2004). Review of research: How leadership influences student learning. Wallace Foundation. (2007, December 19). Retrieved from http://www.wallacefoundation.org/NR/rdonlyres/E3BCCFA5-A88B-45D38E27-B973732283C9/0/ReviewofResearchLearningFromLeadership.pdf

Li, J., \& Du, J. (2016). Globalization and decentralization forces in China's higher education administration and management reform (1953-2015): A neo-institutional analysis. USChina Education Review, 6(1), 1-9.

Lucia, A. D., \& Lepsinger, R. (1999). Art and Science of Competency Models: Pinpointing Critical Success Factors in Organizations. San Francisco: Jossey-Bass/Pfeiffer.

Male, T. (2006). Being an Effective Headteacher. London: Paul Chapman Publishing.

Mazlan, I. (2005). Curriculum Change Management: A case study of two Rompin District Secondary Schools. Unpublished Master Theses, University of Malaya, Malaysia.

Megahed, N. (2018). A Critical Review of the Literature and Practice of Competency Modelling. Sustainability and Resilience Conference: Mitiging Risks and Emergency Planning. KnE Social Science, pp. 104-126.

Ministry of Education Malaysia. (2013). Malaysia Education Blueprint, Putrajaya, Ministry of Education.

Ministry of Education Malaysia. (2016). PISA Report for 2015- Programme For International Student Assessment. Putrajaya, Planning and Research in Education Policy Department. Retrieved from https://www.moe.gov.my/index.php/en/pemberitahuan/120pemberitahuan/2016/2747-laporan-programme-for-international-student-assessment2015-pisa-2015?highlight=WyJwaXNhIl0=?templateStyle=16 
Ministry of Education Malaysia. (2018). 2017 Annual Report: Malaysia Education Blueprint 20132025. Putrajaya: Education Performance and Delivery Unit (PADU). Retrieved from https://www.padu.edu.my/wp-content/uploads/2018/07/AR2017-English-PPPM-.pdf

Muijs, D., \& Harris, A. (2003). Teacher Leadership-Improvement Through Empowerment? Educational Management and Administration, 31(4), 437-449.

Muijs, D., \& Harris, A. (2006). Teacher led school improvement: Teacher leadership in the UK. Teaching and Teacher Education, 22(8), 961-972.

Ngui, F. S. H. (2000). Work competences of the heads of science department in the primary schools in Kuching District, Sarawak. Master Thesis, University of Malaysia, Sarawak. Retrieved from https://ir.unimas.my/id/eprint/1736/1/2011-08-thnguiFSH.pdf

Organisation for Economic Co-operation and Development (OECD). (2019a). TALIS 2018 Result (Volume 1): Teachers and School Leaders as Lifelong Learners. Paris: TALIS OECD Publishing.

Organisation for Economic Co-operation and Development (OECD). (2019b). PISA 2018 Results: Combined Executive Summaries Volume I, II, III. Secretary-General of the OECD. https://www.oecd.org/pisa/Combined_Executive_Summaries_PISA_2018.pdf

Organisation for Economic Co-operation and Development (OECD). (1998). Interdisciplinarity in Science and Technology. Directorate for Science, Technology and Industry. Paris: OECD.

Peacock, J. S. (2014). Science Instructional Leadership: The Role of the Department Chair. Science Educator, 23(1), 36-48.

Shafila, J. (2008). Leadership knowledge, skills of management and the attitude of Heads of Science panels in the zone of Pekan Nanas, Pontian. Master Theses, University of Technology, Malaysia. Retrieved from http://eprints.utm.my/id/eprint/12044/

Singh, A., Yager, S. O., Yutakom, N., Yager, R. E., \& Ali, M. M. (2012). Constructivist teaching practices used by five teacher leaders for the lowa Chautauqua professional development program. International Journal of Environmental \& Science Education, 7, 197-216.

Sinha, S., \& Hanuscin, D. L. (2017). Development of teacher leadership identity: A multiple case study. Teaching and Teacher Education, 63: 356-371.

Spencer, Jr. L. M., \& Spencer, S. M. (1993). Competence at Work: Models for Superior Performance. New York: John Wiley \& Sons.

Spillane, J. P. (2013). The practice of leading and managing teaching. In Educational Research and Innovation Leadership for $21^{\text {st }}$ Century Learning, pp. 59-82. OECD Publishing.

Teacher Training Agency (TTA). (1998). National Standards for Subject Leaders. London: HMSO.

Thompson, K. (2010). How strategic is the school-based planning for leadership succession? International Studies in Educational Administration, 38(1): 98-113.

Turner, C. (2012). Taking Responsibility for Learning and Teaching: From Principles to Practice. London: Continuum International Publishing Group.

Turner, C. (2005). How to Run your Department Successfully. London: Continuum International Publishing Group.

Wan, N. A. M. (2017). Implementation of collaborative leadership practices among instructional leaders to empower elementary school mathematics education. Doctorate Theses, University of Malaya, Malaysia. Retrieved from https://core.ac.uk/download/pdf/84758945.pdf 
INTERNATIONAL JOURNAL OF ACADEMIC RESEARCH IN PROGRESSIVE EDUCATION AND

DEVELOPMENT

Vol. 9, No. 2, 2020, E-ISSN: 2226-6348 @ 2020 HRMARS

Wenner, J. A., \& Campbell, T. (2017). The Theoretical and Empirical Basis of Teacher Leadership a Review of the Literature. Review of Educational Research, 87(1), 134-171. 